\title{
Influences of Aluminium / E-Glass Volume Fraction on Flexural and Impact Behaviour of GLARE Hybrid Composites
}

\author{
Santhosh M. S. , Sasikumar R.
}

Selvam College of Technology, NH 7 Salem Road, Namakkal, 637003 Tamilnadu, India

\author{
Article info: \\ Paper received: \\ The final version of the paper received: \\ Paper accepted online:
}

October 23, 2018

December 12, 2018

December 16, 2018
*Corresponding Author's Address: mozhuguan.santhosh@gmail.com

\begin{abstract}
Composites with different configuration of fiber (E-Glass) and metal (Aluminium) laminates were fabricated and tested for grasping optimum hybrid structure. GLARE (Glass laminate aluminium reinforced epoxy) is a unique composite recently being used by wide engineering domains like defense body and vehicle armors, aerospace, marine and structural applications. The GLARE hybrid composites are manufactured by adding very thin layer of aluminium sheets (surface treated) on the surface of unidirectional E-Glass fiber fabrics in presence of epoxy polymer. Firstly three hybrid GLARE laminates were fabricated with different volume fractions. Consequently, impact and flexural behaviors are measured by izod, charpy impact and flexural tests for all volume configurations. Impact resistance of such hybrid laminate is intensively great. The results depicts that the linear metal volume fraction (MVF) increment on fiber metal laminates greatly increases impact energy absorption capacity of composites and little difference in flexural modulus. Finally the fractured surfaces were analyzed by optical microscope.
\end{abstract}

Keywords: GLARE composite, impact energy, flexural test, epoxy polymer, aluminium sheet, E-Glass fiber.

\section{Introduction}

The authentic approach and supplementary evolution of GLARE / Fiber metal laminates (FML's) are commenced in 1980-90's to use in the high fatigue areas of civil modern aircrafts (Airbus A380 upper fuselage) and defense armors [1]. The exclusive nature of polymer composites such as low crack propagation rate and higher tolerance on damage pushes the researchers to utilize it among various engineering applications. PMC's are well known for its enhanced mechanical properties and tailorability [2]. Glass fibers are one of the emerging and versatile materials available in practically incalculable quantity and supply. Silica is a major chemical constituent of glass fiber. It exhibits appropriate property like transparency, electrical and chemical resistivity, inertness and stability [3-5]. Castrodeza [6] used compliance technique to calculate crack resistance of Bidirectional compact tension GLARE composite specimens and reported that elastic compliance technique provides highly accurate and predictable results on flexural and crack propagation behavior of the GLARE composites (Table 1).

In [8] Gopalakrishnan Ramya Devi fabricated fiber metal sandwich (Hand layup process) structure made up of aluminium sheet AA1050, woven E-Glass Fabric rein- forced with epoxy polymer and analyzed various drilling parameters and reported that influence of stacking sequence on impact parameters of fiber metal configuration.

Santiago reported that higher volume fraction of metal layers results in good impact resistance [9]. Gonzalez studied tensile behavior of low ductile aluminium reinforced FML's and reported that an increase in the metal composition may results in higher strain to failure [10]. Aghamohammad et al., studied surface morphologies of various fractured fiber metal laminates by using profilometry, SEM and optical microscopy, they reported that FPL-Etching and anodizing treatments remarkably improves the flexural properties of FML's [11].

This proposed work focuses on fabrication of hybrid GLARE composites with different fiber metal laminate (FML) volume fraction; flexural and impact study of hybrid configurations under varying load conditions; fractured surface morphological analysis with different magnification ratios by using Olympus metallurgical microscope; identification of optimum hybrid structure for proposed applications. 


\section{Research Methodology}

\subsection{Material}

The epoxy LY 556 polymer base matrix (density $0.9 \mathrm{~g} / \mathrm{cm}^{3}$, viscosity $1.25 \cdot 10^{4} \mathrm{cP}$ ) was used to fabricate hybrid laminates supplied by Covai Seenu and Company, Coimbatore, Tamilnadu-India. W152 LR hardener (density $1.2 \mathrm{~g} / \mathrm{cm}^{3}$, viscosity $1.30 \cdot 10^{4} \mathrm{cP}$ ) used as resin acceleration catalyst. The resin hardener mixed in the proportion of 65/35. AA 2024 (thickness per layer $0.1 \mathrm{~mm}$ ) laminated E-Glass fiber with areal density of $200 \mathrm{~g} / \mathrm{m}^{2}$ supplied by Hindustan composite solutions, Mumbai-India, is utilized as reinforcement. Properties of reinforcements are shown in Table 1.

Table 1 - Properties of reinforcement, MPa

\begin{tabular}{|l|c|}
\hline \multicolumn{1}{|c|}{ Parameter } & Value \\
\hline Maximum strength & 35 \\
\hline Young modulus & $2.45 \cdot 10^{5}$ \\
\hline Fracture toughness & 229 \\
\hline Yield Stress & 365 \\
\hline
\end{tabular}

\subsection{Laminates preparation}

The volume fraction of a resin-fiber mixture is calculated by the following relationship:

$$
V_{f}=\frac{W_{f} / \rho_{f}}{\frac{W_{m}}{\rho_{m}}+\frac{W_{f 1}}{\rho_{f 1}}+\frac{W_{f 2}}{\rho_{f 2}}},
$$

where $W_{f 1,2}, W_{m}$ - weight of fibers 1,2 and matrix; $\rho_{f 1,2}, \rho_{m}$ - density of fibers 1,2 and matrix.

The reinforcement and matrix volume fraction of all the three hybrid laminates were depicted in Table 2.

Table 2 - FML volume fraction, $\%$

\begin{tabular}{|c|c|c|}
\hline Specimen & $\begin{array}{c}\text { Reinforcement } \\
\text { (Al + E-Glass) }\end{array}$ & $\begin{array}{c}\text { Matrix } \\
\text { (Epoxy) }\end{array}$ \\
\hline GLARE 1 & 70 & 30 \\
\hline GLARE 2 & 65 & 35 \\
\hline GLARE 3 & 60 & 40 \\
\hline
\end{tabular}

Similarly micro surface of the specimens before testing is exposed in Figure $1 \mathrm{a}, \mathrm{b}$ in the magnification ratio of $100 \mathrm{X}$ and $200 \mathrm{X}$ respectively.

In the proposed study GLARE hybrid composites with different volume fraction configurations were fabricated by Vacuum Assisted Resin Transfer Molding Process, which is well known for its quality of finishing and nonpores strong products. Three hybrid laminates $(250 \times 250 \mathrm{~mm}$ plate $)$ as shown in Table 2 were fabricated and samples were prepared as per ASTM standard by water jet machining process. The surface and edge smoothened samples of Impact (izod and charpy) and Flexural tests are shown in Figure 1.

\subsection{Characterization}

The impact tests were carried out by the AIT-300N impact pendulum which has strike velocity of $5.6 \mathrm{~m} / \mathrm{sec}$, pendulum diameter $1600 \mathrm{~mm}$, hammer weight $18.7 \mathrm{~kg}$. ASTM D256 and ASTM D6110 standards were followed for izod and charpy tests respectively. The three point bending tests were done for specimens made as per ASTM 790 standard $(80 \times 13 \times 3 \mathrm{~mm})$ using Instron 4486 (short head speed $4 \mathrm{~mm} / \mathrm{min}$ ). The test results are reported for various hybrid GLARE laminates.

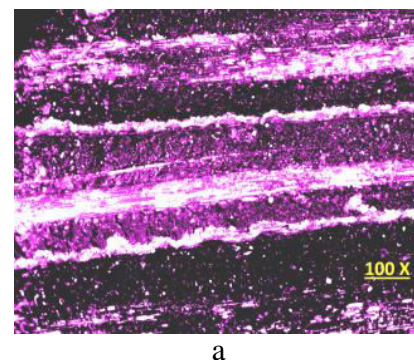

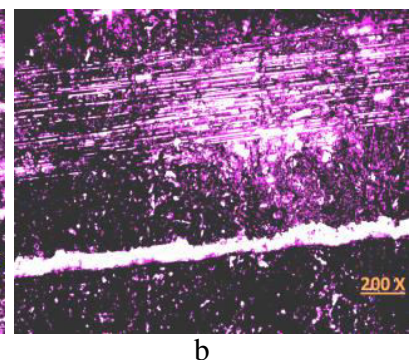

b
Figure 1 - Optical microscope images of specimens before test for the magnification ratio $100 \mathrm{X}$ (a) and $200 \mathrm{X}$ (b)

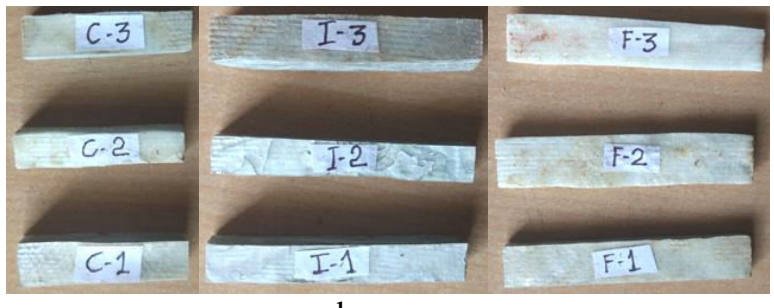

a

b

c

Figure 2-Charpy (a), Izod (b) and flexural (c) impact test specimens

\section{Results and Discussion}

\subsection{Impact tests}

Charpy and izod impact test results of hybrid GLARE laminates were shown in Figure 3. The $70 \%$ fiber metal laminate reinforced composites shows better impact resistance than other two composites.

Comparison of energy absorption rate of fiber metal laminates shows that the higher FML volume results in better energy absorption. The above results clearly depicts among 60, 65, and $70 \%$ of fiber volume fractions 60 and $70 \%$ FML shows good resistance against impact energy where as $35 \%$ epoxy matrix GLARE laminate has moderate impact resistance. Specimen 3 (70 \% FML reinforced) absorbs $15 \%$ higher impact load than other two configurations due to its great inter facial bonding between metal laminates and matrix. Results show that higher the volume fraction possesses better mechanical properties. 


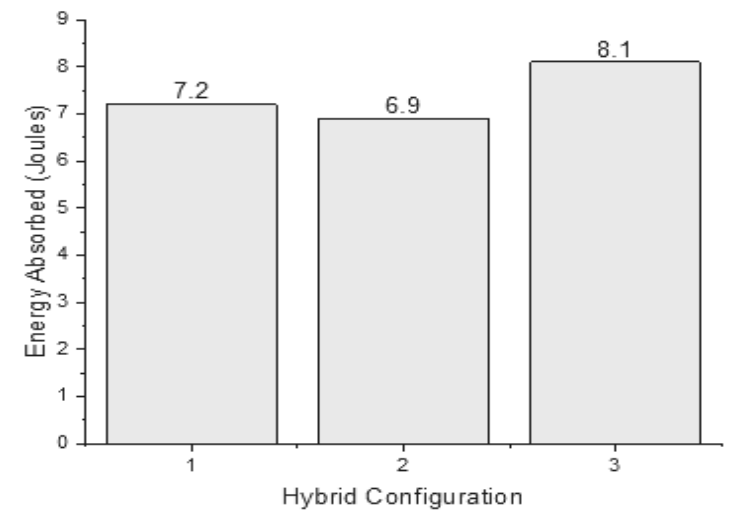

a

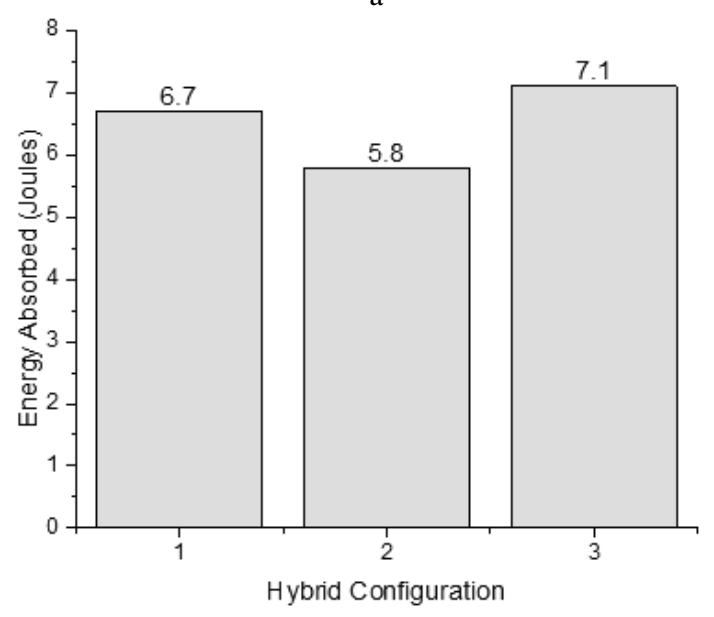

b

Figure 3 - Izod (a) and Charpy (b) impact test results

\subsection{Flexural test}

Figures 4 and 5 provides the stress-strain and force displacement relationship curves 60,65 , and $70 \%$ of fiber metal reinforced laminates. Among these three hybrid laminates $65 \%$ FML reinforced samples shows $20 \%$ higher flexural modulus than other two configuration. It clearly indicates that moderate FML reinforcement improves the flexural property significantly.

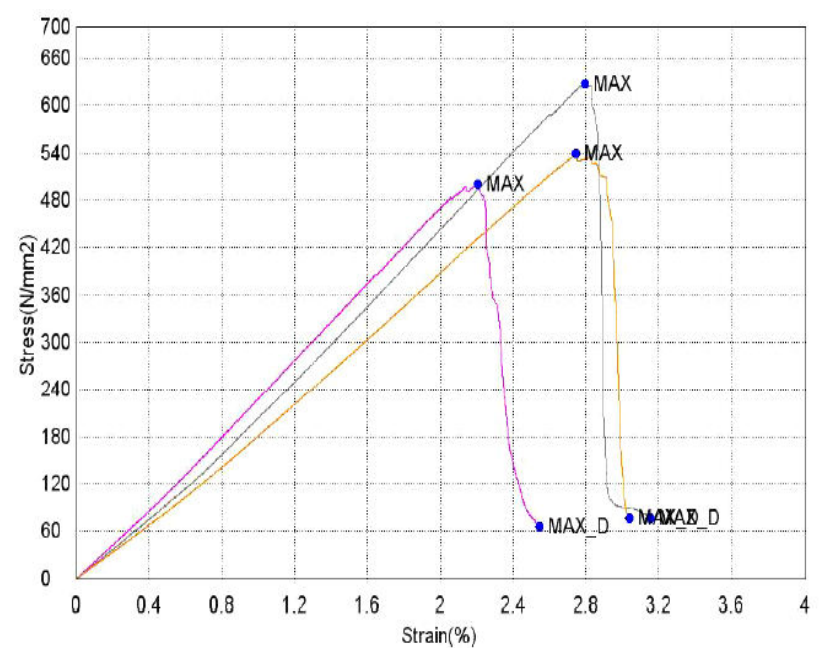

Figure 4 - Stress-strain curve

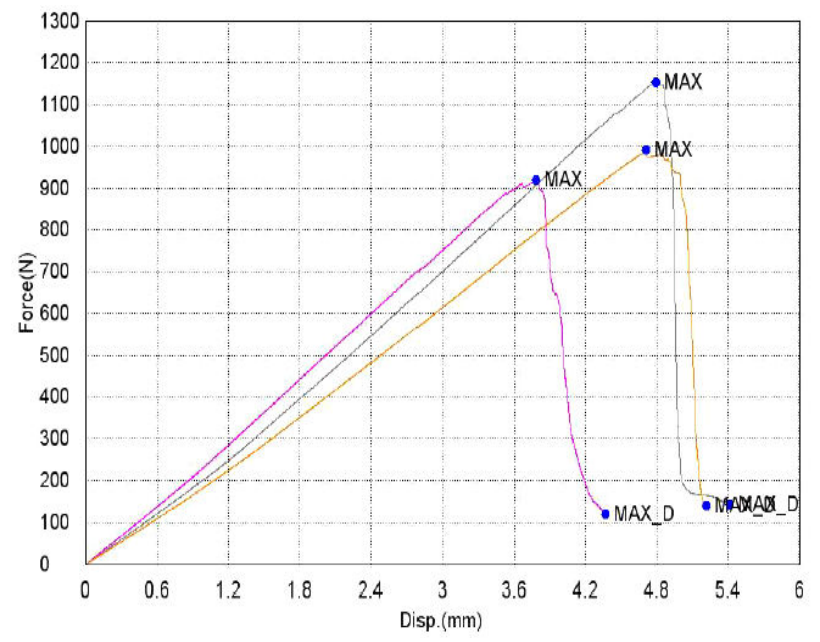

Figure 5 - Force-displacement curve

\subsection{Optical microscope analysis}

The characteristics of the flexural and impact tested composite surfaces of the proposed work are studied with optical microscope (Olympus Metallurgical Microscope). Cross sectional specimens of fractured surface were prepared for analysis. The observed microscope images containing matrix material, Aluminium and E-Glass laminates are shown in Figure 6.

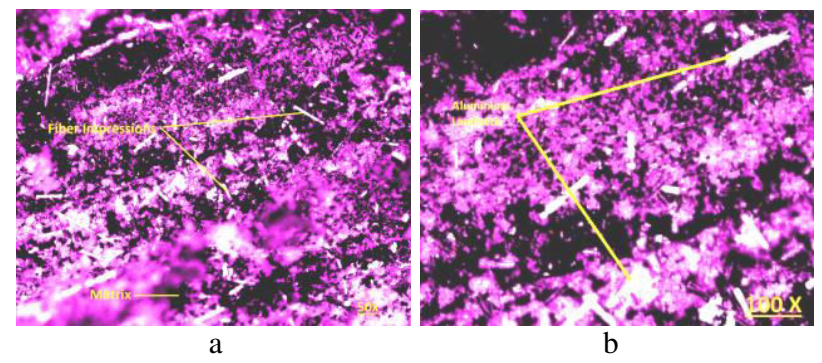

Figure 6 - Cross-sectional optical microscope images of fractured surface for matrix (a) and Aluminium / E-Glass laminates (b)

The results portrays that the deformation or breaking of fiber laminates are restricted by the aluminium reinforcement. Contemporaneously aluminium laminates shows uneven fracture. These phenomena spectacles the moderate weight percentage inclusion of FML considerably enhances the mechanical properties of GLARE.

\section{Conclusions}

Epoxy matrix aluminium laminated glass fiber reinforced (GLARE) composites fabricated by vacuum assisted resin transfer molding with different volume fractions and its impact, flexural behavior and fracture surface analysis were done. The test results shows that higher fiber metal laminate volume possesses excellent impact resisting property, dynamic mechanical property and very minor crack propagation, whereas moderate FML volume possess good flexural property than higher volume of 
FML. Both the static and dynamic mechanical testing reveals that inclusion of metal layers into the fibers provides higher resistance to catastrophic failure. The proposed outcome of this research is suitable for high strength aerospace applications, armors of the defense industry and high impact ballistic profiles.

\section{Acknowledgements}

Authors appreciate the management of Selvam College of Technology for the deliberate support to carry out this research at Selvam Composite Material Research Laboratory (SCMRL), Namakkal, Tamilnadu, India.

\section{References}

1. Van, R., Sinke, J., de Vries, T., \& van der Zwaag, S. (2004). Property optimization in fiber metal laminates. Applied Composite Materials, Vol. 11(2), pp. 63-76.

2. Wang, R. M., Zheng, S. R., \& Zheng, Y. G. (2011). Polymer Matrix Composites and Technology. Elsevier.

3. Wallenberger, F. T., Watson, J. C., \& Li, H. (2001) Glass Fibers. Materials Park, ASM International.

4. Vlot, A., Kroon, E., \& Rocca, G. L. (1997). Impact response of fiber metal laminates. Key Engineering Materials, Vol. 141, pp. 235-276.

5. Cortes, P., \& Cantwell, W. (2006). The fracture properties of a fiber-metal laminate based on magnesium alloy. Composites: Part B, Vol. 37, pp. 163-170.

6. Castrodeza, E., Soldan, L., \& Bastian, F. (2006). Crack resistance curves of GLARE laminates by elastic compliance. Congresso Brasileiro de Engenharia e Ciencia dos Materials.

7. Karatas, M. A., \& Gokkaya, H. (2018). A review on machinability of carbon fiber reinforced polymer (CFRP) and glass fiber reinforced polymer (GFRP) composite materials. Defence Technology, doi: 10.1016/j.dt.2018.02.001.

8. Devi, G. R., \& Palanikumar, K. (2018). Analysis on drilling of woven glass fibre reinforced aluminium sandwich laminates. Journal of Materials Research and Technology, doi: 10.1016/j.jmrt.2018.06.021.

9. Santiago, R. C., Cantwell, W. J., Jones, N., \& Alves, M. (2018). The modelling of impact loading on thermoplastic fibre-metal laminates. Composite Structures, Vol. 189, pp. 228-238.

10. Gonzalez-Canche, N. G., Flores-Johnson, \& E. A., Carrillo, J. G. (2017). Mechanical characterization of fiber metal laminate based on aramid fiber reinforced polypropylene. Composite Structures, Vol. 172, pp. 259-266.

11. Aghamohammad, H., Abbandanak, N. H., Eslami-Farsani, R., \& Siadati, S. M. H. (2018). Effects of various aluminum surface treatments on the basalt fiber metal laminates interlaminar adhesion. International Journal of Adhesion and Adhesives, doi: 10.1016/j.ijadhadh.2018.03.005.

12. Santhosh, M. S., Sasikumar, R., Natrayan, L., Kumar, M. S., Elango, V., \& Vanmathi, M. (2018). Investigation of mechanical and electrical properties of Kevlar / E-glass and Basalt / E-glass reinforced hybrid composites. International Journal of Mechanical and Production Engineering Research and Development, Vol. 8(3), pp. 591-598.

13. Hassan, M. K., Abdellah, M. Y., Azabi, S. K., \&Marzouk, W. W. (2015). Fracture Toughness of a Novel GLARE Composite Material. International Journal of Engineering and Technology, Vol. 15(6), pp. 36-41.

14. Golshahr, A., Natarajan, E., Santhosh, M. S., Sasikumar, R., Ramesh, S., \&Durairaj, R. (2018). Multiwall Carbon Nanotube Reinforced Silicone for Aerospace Applications. International Journal of Mechanical and Production Engineering Research and Development, Vol. 8(4), pp. 743-752.

15. Crupi, V., Kara, E., Epasto, G., Guglielmino, E., \& Aykul, H. (2014). Prediction model for the impact response of glass fiber reinforced aluminium foam sandwiches. International Journal of Impact Engineering, doi: 10.1016/j.ijimpeng.2014.11.012.

16. Kumar, S., Shivashankar, G. S., Dhotey, K., \& Singh, J. (2017). Experimental study wear rate of glass fiber reinforced epoxy polymer composites filled with aluminium powder. Materials Today, Vol. 4, pp. 10764-10768.

17. Mariam, M., Afendi, M., Majid, M. S. A., Ridzuan, M. J. M., \& Gibson, A. G. (2017). Tensile and fatigue properties of single lap joints of aluminium alloy/glass fiber reinforced composites fabricated with different joining methods. Composite Structures, doi: 10.1016/j.compstruct.2018.06.003.

18. Sarkar, P., Modak, N., \& Sahoo, P. (2018). Mechanical and Tribological Characteristics of Aluminium Powder filled Glass Epoxy Composites. Materials Today, Vol. 5, pp. 5496-5505.

19. Trzepiecinski, T., Kubit, A., et al. (2018). Strength properties of aluminium/glass-fiber reinforced laminate with additional epoxy adhesive film interlayer. International Journal of Adhesion and Adhesives, doi: 10.1016/j.ijadhadh.2018.05.016.

20. Rajkumar, G. R., Krishna, M., et al. (2014). Investigation of tensile and bending behaviour of aluminium based hybrid fiber metal laminates. Proceedia Material Science, Vol. 5, pp. 60-68. 


\title{
Вплив об’смної концентрації алюмосилікатних фолокон на гнучкість гібридних алюмополімерних композитів
}

\author{
Сантош М. С., Сашікумар Р.
}

Технологічний коледж Сільвам, 7 Салем шлях, 637003, Намакхал, м. Тамілнаду, Індія

\begin{abstract}
Анотація. Композити з різною структурою алюмосилікатних волокон були виготовлені і випробувані для отримання оптимальної гібридної структури. Алюмополімерний композит $є$ унікальним матеріалом, який останнім часом має широку сферу використання в інженерії, оборонному комплексі, транспортних засобах, аерокосмічній і морській галузях. Гібридні композити GLARE виробляються із додаванням надтонкого поверхнево обробленого шару алюмінію на поверхні однонаправлених тканин E-Glass iз включеннями епоксидного полімеру. Спочатку було виготовлено декілька матеріалів GLARE з різним фракційним складом. У результаті досліджувалась поведінка матеріалу при згинанні для виявлення усіх параметрів гнучкості. Виявлено надвеликий коефіцієнт ударного опору такого гібридного матеріалу. Результати показали, що збільшення концентрації металу значно збільшує здатність поглинання енергії на композит, а також підтвердили незначну зміну модуля пружності першого роду. Наостанок, зруйновані поверхні були досліджені із застосуванням оптичного мікроскопу.
\end{abstract}

Ключові слова: алюмополімерний композит, енергія впливу, тест на гнучкість, епоксидний полімер, алюмінієвий лист, алюмосилікатне волокно. 